\title{
ANALISIS RISIKO BENCANA ERUPSI GUNUNG MERAPI DI KECAMATAN DUKUN KABUPATEN MAGELANG
}

\author{
Oleh: \\ Andika Surya Ardi, Dyah Respati Suryo Sumunar \\ Jurusan Pendidikan Geografi FIS UNY
}

\begin{abstract}
Abstrak
Penelitian ini bertujuan mengetahui: (1) Tingkat risiko bencana erupsi Gunung Merapi,(2) Sebaran risiko bencana erupsi Gunung Merapi; di Kecamatan Dukun Kabupaten Magelang. Populasi dalam penelitian ini adalah seluruh wilayah Kecamatan Dukun. Sampel diambil menggunakan metode area sampling berdasarkan Peta Kawasan Rawan Bencana (KRB) Gunung Merapi. Pengumpulan data dilakukan dengan wawancara, observasi, dan dokumentasi. Analisis data yang digunakan adalah skoring, overlay, dan penafsiran deskriptif.Hasil penelitian: (1) Tingkat risiko bencana erupsi dapat dibagi menjadi: Sedang, rendah, dan sangat rendah. Semakin tinggi tingkat risiko bencana maka potensi kerugian akibat terjadinya bencana erupsi Gunung Merapi semakin besar. (2) Risiko bencana erupsi terdapat diseluruh wilayah. Sebaran tingkat risiko sedang mendominasi sebagian wilayah Desa Sengi dan Desa Kalibening. Sebaran tingkat rendah mendominasi sebagian besar wilayah Desa Ketunggeng, Desa Banyubiru, Desa Ngadipuro, Desa Wates dan Desa Banyudono. Sebaran tingkat sangat rendah berada di Desa Sewukan, Desa Mangunsoko, Desa Dukun, Desa Kalibening, Desa Sumber, Desa Paten, Desa Krinjing, Desa Sengi dan Desa Ngargomulyo.
\end{abstract}

Kata Kunci: Risiko Bencana, Gunung Merapi, Kecamatan Dukun

\section{Abstract}

This research aims at investigating (1) the level of disaster risk of Merapi Volcano, (2) the distribution of Merapi Volcano disaster risks in Dukun Subistrict, Magelang regency. The population includes all areas in Dukun Subdistrict. The samples were taken using area sampling technique based on the map of disaster-prone areas. The data collection employed interviews, observations, and documentations. The data analysis consists of scoring, overlay, and descriptive interpretation. The results are: (1) the level of disaster risk of Merapi Volcano eruption is divided into medium, low, and very low. The higher level of the disaster risk, the greater of the potential loss due to Merapi volcano eruption will be. (2) The distribution of disaster risk spreads throughout the areas. Medium level risk distributes in some parts of Sengi and Kalibening Village. Low level risk dominates Ketunggeng, Banyubiru, Ngadipuro, Wates, and Banyudono Village. Very low level risk spreads in Sewukan, Mangunsoko, Dukun, Kalibening, Sumber, Paten, Krinjing, Sengi, and Ngargomulyo Village.

Keywords: Disaster risk, Merapi Volcano, Dukun Subdistrict

\section{PENDAHULUAN}

Indonesia merupakan negara kepulauan yang terletak pada pertemuan tiga lempeng besar dunia yaitu Eurasia, Hindia-Australia, dan Pasifik. Tiga sistem lempeng 
tersebut menghasilkan situasi morfostruktur yang berbentuk busur kepulauan, dikelilingi oleh basin laut dalam dan palung (Verstappen, 2013: 7-8). Kondisi ini menjadikan wilayah Indonesia sebagai jalur tektovulkanik aktif, yang ditandai oleh banyak terjadi peristiwa gempabumi dan aktivitas vulkanik.Menurut Sudibyakto (2011: 109) rangkaian aktivitas vulkanik akibat dari meningkatnya aktivitas kegempaan pada zone subduksi yang membentang dari sebelah barat Sumatra, selatan Jawa, Bali, NTB, NTT, dan Sulawesi serta Papua. Jalur ini dikenal pula sebagai "Ring of Fire" yang meliputi deretan gunungapi dan 129 diantaranya masih aktif.

Kawasan gunungapi merupakan wilayah dengan ketersediaan sumberdaya yang tinggi. Kegiatan gunungapi mampu menghasilkan bahan-bahan yang memperkaya dan meremajakan tanah untuk pertanian. Tubuh gunungapi yang tinggi merupakan penangkap hujan dan penyimpan serta pemasok airtanah. Ketersedian sumberdaya alam merupakan daya tarik tersendiri bagi penduduk, sehingga kawasan gunungapi pada umumnya menjadi konsentrasi penduduk, dengan bukti kepadatan penduduk yang tinggi (Sutikno, dkk, 2007: 33-34).Di sisi lain erupsi gunungapi dapat menyebabkan berbagai kerusakan. Wesnawa dan Christiawan (2014: 85) menjelaskan, terdapat berbagai macam kerusakan dan kerugian yang diakibatkan oleh bencana erupsi gunungapi, yaitu kehancuran tata ruang wilayah, penurunan kualitas lingkungan, kerusakan sarana prasarana lalu lintas, dan kerusakan bangunan pusat aktivitas masyarakat dan lain-lain. Dampak dari kerusakan yang ditimbulkan juga dapat menyebabkan terganggunya aktivitas kehidupan penduduk, lumpuhnya sektor perekonomian, dan bahkan dapat mengganggu jalannya kegiatan pembangunan nasional.

Verstappen (2013: 67) menjelaskan, gejala vulkanisme di Indonesia paling banyak dijumpai di Pulau Jawa dengan 23 gunungapi tipe-A. Berdasarkan sejarah pernah terjadi 470 erupsi atau $47 \%$ dari seluruh erupsi total yang pernah terjadi di Indonesia. Aktivitas vulkanisme kebanyakan terletak di sisi selatan gunungapi. Rangkaian gunungapi di Pulau Jawa memanjang dari barat ke timur. Salah satu gunungapi yang paling aktif adalah Gunung Merapi sejak awal Holosenhingga kini. Gunung Merapi merupakan salah satu gunungapi tipe strato yang dikenal sebagai salah satu gunungapi aktif di Indonesia, bahkan di dunia (Ma'arif dan Hizbaron, 2014: 6).Erupsi besar terakhir terjadi pada tahun 2010. Letusan tahun 2010 menyebabkan 2682 rumah rusak berat di DIY dan 174 rumah rusak berat di Jawa Tengah (Ma'arif dan Hizbaron, 2014: 6). Secara umum Kerusakan yang diakibatkan oleh erupsi Gunung Merapi berdampak pada sektor permukiman, infrastruktur, sosial, ekonomi, dan lintas sektor yang mengakibatkan terganggunya aktivitas dan pelayanan umum di daerah sekitarnya (Sutikno dkk, 2007: 20-21).

Kecamatan Dukun terletak di lereng sebelah barat Gunung Merapi. Kondisi topografi seperti relief pegunungan dan lembah-lembahnya sangat dipengaruhi oleh aktivitas vulkanik Gunung Merapi. Karena dipengaruhi oleh aktivitas vulkanik, wilayah ini banyak menghadapi potensi bencana erupsi. Selain itu, pasca erupsi tahun 2010 diduga telah banyak terjadi perubahan morfologi yang menyebabkan perubahan persebaran potensi bahaya, termasuk Kecamatan Dukun yang sebagian wilayahnya memiliki potensi bahaya tinggi dan sangat tinggi (Setyawati dkk, 2013: 139; Setyawati dkk, 2013: 27). Di sisi 
lain Gunung Merapi memberikan banyak manfaat terutama lahan yang subur sehingga banyak dimanfaatkan oleh penduduk yang tinggal disekitarnya. Dengan kondisi lahan yang subur, pada umumnya penduduk di lereng Gunung Merapi bekerja pada sektor pertanian. Selain itu juga banyak terdapat tambang bahan galian $\mathrm{C}$ berupa pasir dan batu yang melimpah, walaupun sesungguhnya mereka sangat dekat dengan sumber ancaman.

Kecamatan Dukun di Kabupaten Magelang memiliki jumlah penduduk terdampak bencana erupsi Gunung Merapi terbanyak yang meliputi 8 dari 15 Desa terletak di Kawasan Rawan Bencana (KRB) III.Faktor-faktor bahaya di Kecamatan Dukun merupakan suatu keadaan yang tidak dapat diubah.Hal ini merupakan konsekuensi dari kondisi secara geologis, geomorfologis, dan klimatis dari posisinya. Potensi terjadinya bencana di Kecamatan Dukun tidak hanya dipengaruhi oleh faktor bahaya vulkanik saja, tetapi juga faktor kerentanan dan kapasitas bencana. Potensi terjadinya bencana membawa konsekuensi kesiapsiagaan penduduk di Kecamatan Dukun. Penanggulangaan bencana harus diawali informasi mengenai risiko bencana alam dan kesiapsiagaan masyarakat terhadap bencana yang berpotensi terjadi.

Informasi tingkat risiko bencana dapat dimanfaatkan baik dalam pra bencana, penanganan darurat pada saat bencana, maupun pemulihan pasca bencana. Kajian mengenai tingkat risiko bencana dapat digunakan untuk menganalisis tingkat bahaya yang terjadi dan tingkat kerentanan fisik, sosial, ekonomi serta lingkungan penduduk di Kecamatan Dukun dalam menghadapi bencana. Kajian risiko bencana juga dapat digunakan untuk mengetahui tingkat kapasitas atau kemampuan penduduk dan pemerintah dalam menghadapi bencana. Analisis tingkat dan sebaran risiko perlu dilakukan di Kecamatan Dukun sebagai wilayah yang rawan bencana erupsi gunungapi.

\section{METODE}

Penelitian ini berdasarkan cara dan taraf pembahasan masalah merupakan penelitian deskriptif. Berdasarkan bentuk dan metode pelaksanaannya, penelitian inimenggunakan metode survey. Penelitian ini mendeskripsikan segala sesuatu yang terdapat di lapangan yang berhubungan dengan bahaya erupsi Gunung Merapi di Kecamatan Dukun serta kaitannya dengan kerentanan dan kapasitas penduduk di wilayah tersebut. Survei yang dilakukan pada penelitian ini juga dilakukan untuk gejala fisik yang merupakan objek yang tidak dapat diwawancarai, namun atribut terkait dari objek dapat diketahui melalui pengukuran dan pengamatan langsung dilapangan.

Populasi dalam penelitian ini adalah seluruh desa di Kecamatan Dukun. Cara pengambilan sampel dalam penelitian ini menggunakan metode sampel daerah (area sampling). Sampel yang diambil berupa sampel bahaya, kerentanan, dan kapasitas untuk nantinya mengetahui tingkat dan sebaran risiko yang ada di Kecamatan Dukun.Analisis yang digunakan antara lain: analisis pengharkatan (scoring), Analisis Tumpang-susun Peta (Overlay) dalam Sistem Informasi Geografi (SIG), dan Analisis Deskriptif. Scoring dilakukan untuk memberikan nilai pada masing masing variabel bahaya, kerentanan dan kapasitas untuk mengetahui tingkat dan sebaran resiko bencana.Analisis overlay dilakukan dengan melakukan tumpang susun peta pada masing-masing variabel bahaya, kerentanan, dan 
kapasitas. Analisis deskriptif dilakukan dengan menggunakan peta tingkat risiko bencana erupsi Gunung Merapi. Deskripsi sebaran meliputi luas wilayah sebaran masing-masing tingkat risiko dan lokasi keberadaan masing-masing tingkat risiko di setiap desa atau kelurahan di Kecamatan Dukun.

\section{HASIL DAN PEMBAHASAN}

\section{Daerah Penelitian}

Kecamatan Dukun Merupakan merupakan salah satu kecamatan di Kabupaten Magelang yang terletak sekitar 18 kilometer dari pusat pemerintahan Kabupaten Magelang. Kecamatan Dukun dibagi menjadi 15 desa, 145 dusun, 154 RW, dan 470 RT. Secara Astronomis Kecamatan Dukun terletak antara 110 01'51'- $110^{\circ} 12^{\prime} 48^{\prime \prime}$ Bujur Timur dan $7^{\circ} 19^{\prime} 13^{\prime \prime}-7^{\circ} 35^{\prime} 99^{\prime \prime}$ Lintang Selatan. Kecamatan Dukun memiliki luas wilayah 53,41 km² (Gambar 1).

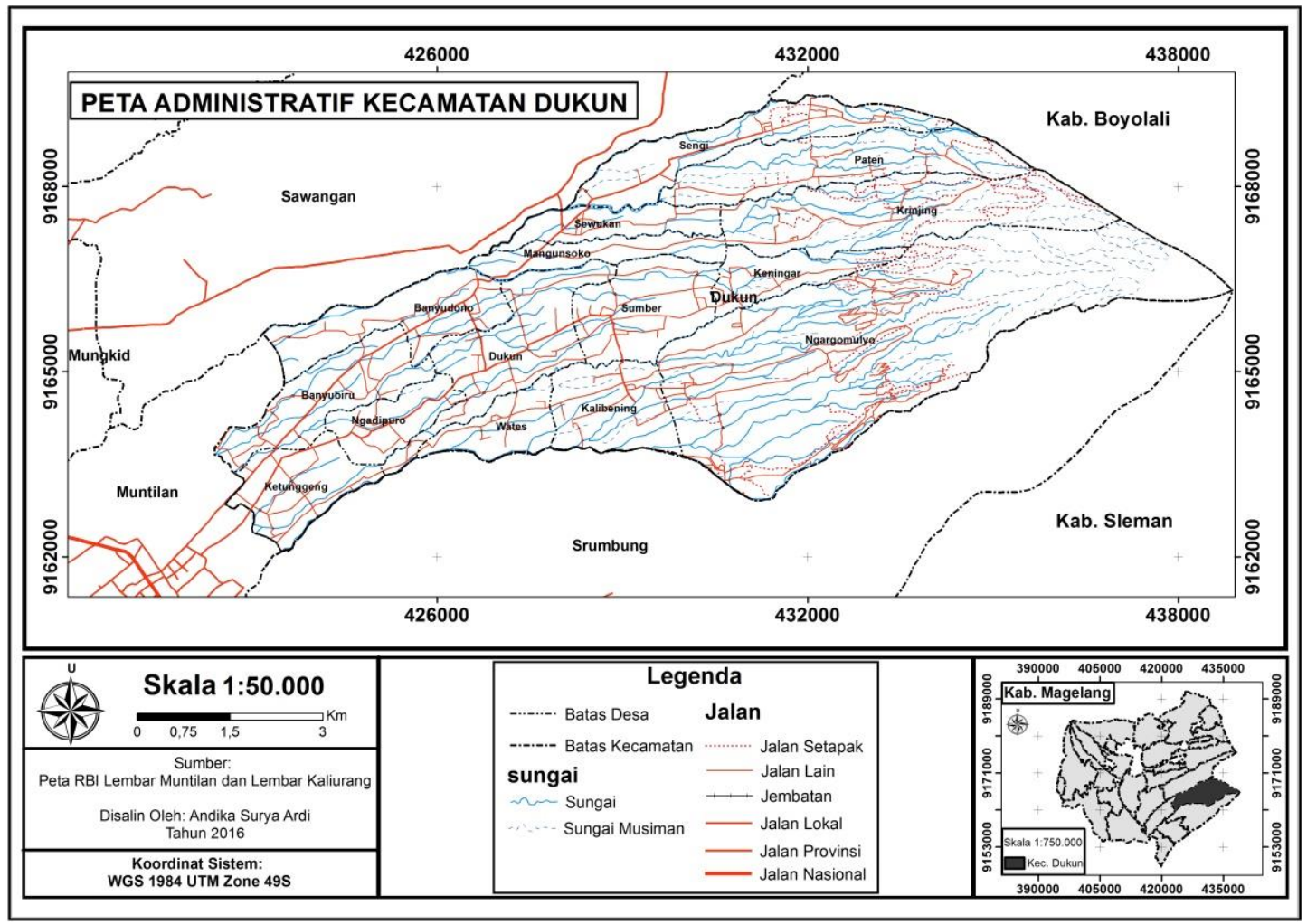

Gambar 1. Peta Aministratif Kecamatan Dukun

Berdasarkan Peta Geologi Lembar Yogyakarta dan Salatiga dengan Skala 1:100.000 Kecamatan Dukun tersusun oleh endapan longsoran awan panas, endapan Gunungapi Merapi Muda, endapan Gunungapi Merapi Muda, Endapan Gunungapi tak terpisahkan serta kubah lava dan leleran yang tersebar di seluruh wilayah penelitian Batuan ini dalam skala waktu geologis telah terbentuk pada zaman quarter.Wilayah Kecamatan Dukun secara geomorfologis merupakan bagian dari wilayah Gunung Merapi yang terdiri dari 
Kerucut Gunungapi, Lereng Gunungapi, Kaki Gunungapi, Dataran kaki Gunungapi, dan dataran fluvial Gunungapi.

Kecamatan Dukun memiliki variasi tingkat kemiringan dari kriteria datar (0-2\%), landai (3-7\%), miring (8-13\%), cukup curam (14-20\%), hingga curam (21-55\%). Tingkat kemiringan datar tersebar di bagian sebelah Barat Kecamatan Dukun meliputi Desa Ketunggeng, Desa Banyubiru, Desa Ngadipuro, Desa Banyubiru, Desa Dukun, Desa Sewukan Dan Desa Mangunsoko. Wilayah Dengan Kriteria Kemiringan yang paling tinggi yaitu curam (21-55\%) berada dibagian timur wilayah Kecamatan Dukun Meliputi Desa Krinjing, Keningar Dan Ngargomulyo. Desa Ngargomulyo Merupakan Desa Yang yang paling dekat dengan puncak Gunung Merapi.

Kecamatan Dukun memiliki variasi ketinggian dari titik yang paling rendah yaitu 400 mdpl sampai dengan titik yang paling tinggi yaitu $2918 \mathrm{mdpl}$ di wilayah desa Ngargomulyo. Wilayah desa yang memiliki ketinggian 400-500 mdpl tersebar dibagian barat meliputi Desa Ketunggeng, Desa Banyubiru dan Desa Ngadipuro. Hampir semua desa berada di ketinggian 500-1000 mpdl. Wilayah di Kecamatan Dukun dengan kriteria ketinggian diatas $1000 \mathrm{mdpl}$ meliputi Desa Krinjing, Desa Paten, Desa Sengi dan Desa Ngargomulyo. Desa Ngargomulyo Merupakan Desa yang paling tinggi dikarenakan dengan dengan Puncak Gunung Merapi.

Penggunaan lahan Kecamatan Dukun didominasi oleh Sawah irigasi dengan luas $2501,65 \mathrm{Ha}$ atau 43,12 \% dari luas seluruh wilayah. Penggunaan lahan ini tersebar di sebelah barat Kecamatan Dukun. Kecamatan Dukun juga memiliki jenis penggunaan lahan berupa Hutan seluas 351,79 atau 6,06\%. Selain itu Kecamatan Dukun juga memiliki jenis penggunaan lahan berupa tanah berbatu seluas 154,10 atau 2,66 \% dikarenakan dekat dengan pusat erupsi Gunung Merapi.

\section{Tingkat Risiko Bencana Erupsi Gunung Merapi Di Kecamatan Dukun Kabupaten Magelang}

Risiko bencana ditentukan dengan menghitung pengaruh bahaya, kerentanan, dan kemampuan dalam menghadapi bencana. Langkah pertama yang dilakukan adalah menentukan tingkat bahaya erupsi.Penentuan tingkat bahaya bencana erupsi Gunung Merapi di Kecamatan Dukun Kabupaten Magelang dilakukan dengan analisis pengharkatan (scoring). Analisis tersebut didasarkan pada Peta Kawasan Rawan Bencana (KRB) Gunung Merapi di Kecamatan Dukun Kabupaten Magelang. Skoring dilakukan dengan ketentuan skor 10 untuk KRB I, skor 20 untuk KRB II, dan skor 30 untuk KRB III.

Tingkat bahaya erupsi Gunung Merapi dibagi meliputi tiga tingkat bahaya yaitu tingkat bahaya rendah, tingkat bahaya sedang, dan tingkat bahaya tinggi. Tingkat bahaya rendah meliputi Desa Ketunggeng, Desa Ngadipuro, Desa Banyudono dan Desa Banyubiru.Tingkat bahaya sedang meliputi Desa Wates, Desa Dukun, dan Desa Mangunsoko.Sedangkan untuk tingkat bahaya tinggi mencakup 8 desa antara lain Desa Kalibening, Desa Ngargomulyo, Desa Keningar, Desa Sumber, Desa Sewukan, Desa Krinjing, Desa Paten, dan Desa Sengi (Gambar 2). 


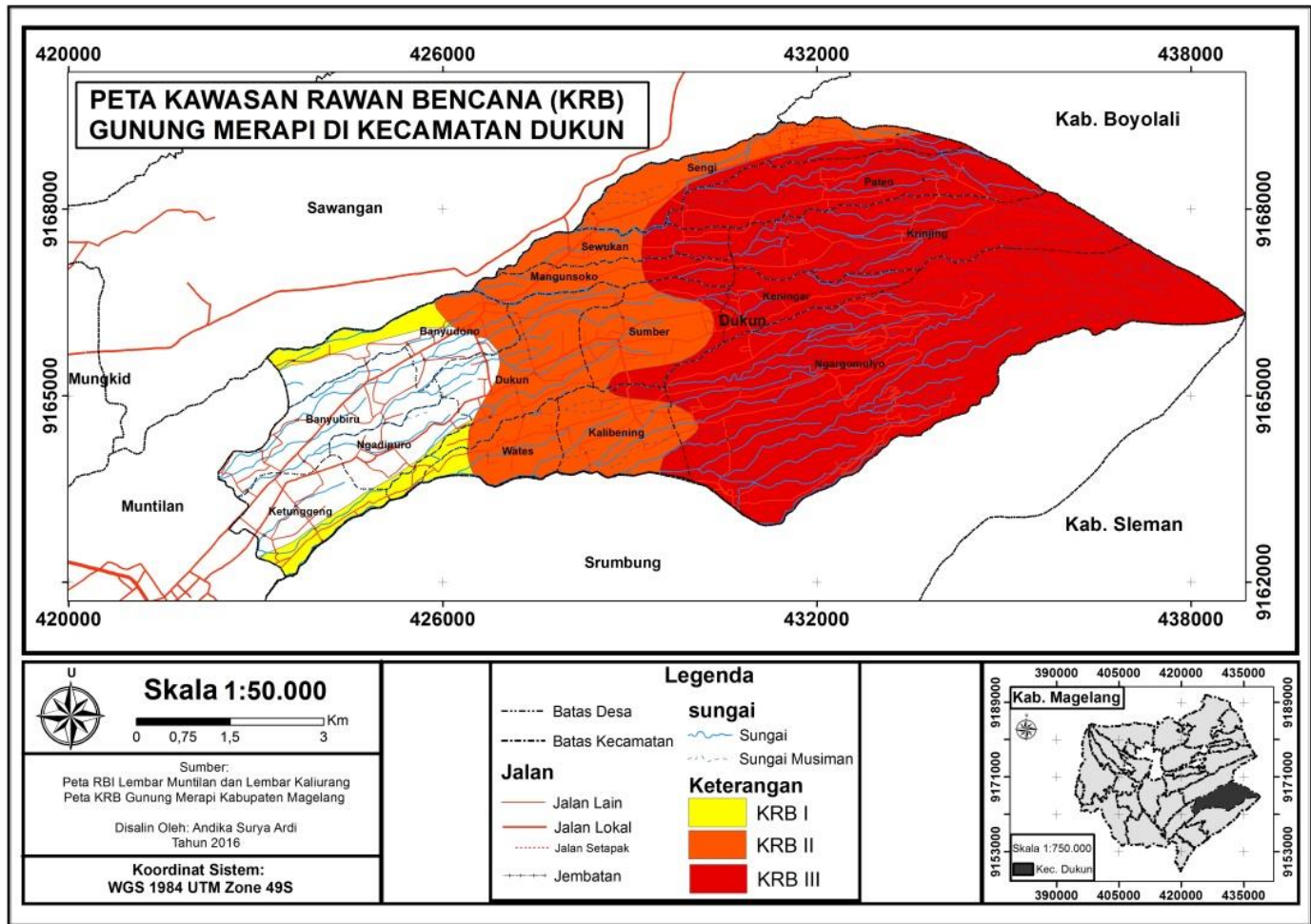

Gambar 2. Peta Tingkat dan Sebaran Bahaya Erupsi Gunung Merapi di Kecamatan Dukun

Langkah berikutnya adalah menentukan tingkat kerentanan. Kerentanan meliputi kerentanan sosial, kerentanan ekonomi, kerentanan fisik, dan kerentanan lingkungan. Hasil total dari perhitungan keempat aspek kerentanan tersebut dinyatakan sebagai tingkat kerentanan yang berpengaruh terhadap risiko bencana.

Kerentanan Sosial meliputi tingkat Kepadatan Penduduk dan rasio kelompok rentan. Tingkat kepadatan penduduk juga mempengaruhi tingkat kerentanan suatu wilayah dalam menghadapi bancana. Tingkat kepadatan penduduk yang lebih tinggi mempunyai tingkat kerentanan yang lebih tinggi apabila dibandingkan dengan wilayah yang mempunyai tingkat kepadatan penduduk yang rendah. Tingkat kepadatan penduduk akan menentukan cara-cara atau perlakuan yang diberikan pemerintah atau pihak-pihak lain saat menangani bencana di wilayah tersebut.

Rasio jenis kelamin tertinggi berada di Desa Sewukan dengan jumlah 51,49\%. Rasio jenis kelamin terendah berada di desa Banyudono dengan jumlah 49,16\%. Untuk tingkat rasio jenis kelamin semua desa di Kecamatan Dukun berada pada tingkat tinggi. Hal ini dikarenakan di semua desa angka perbandingan jumlah penduduk perempuan terhadap jumlah penduduk laki-laki diatas $40 \%$.Rasio kelompok umur tertinggi berada di Desa Wates dengan jumlah 32,45\%. Rasio kelompok umur terendah berada di desa Krinjing dengan jumlah 32,32\%. Untuk tingkat rasio kelompok umur semua desa di Kecamatan Dukun berada pada tingkat sedang. Hal ini dikarenakan di semua desa angka perbandingan jumlah penduduk rentan berada pada kriteria 20-40\%.Rasio orang cacat tertinggi berada di Desa Keningar dengan jumlah 2,48\%. Rasio orang cacat terendah 
berada di desa Sumber dengan jumlah 0,77\%. Untuk tingkat rasio orang cacat semua desa di Kecamatan Dukun berada pada tingkat rendah. Hal ini dikarenakan di semua desa angka perbandingan jumlah penduduk rentan berada pada kriteria $<20 \%$.Rasio kemiskinan tertinggi berada di Desa Ketunggeng dengan jumlah 22,11\%. Rasio kemiskinan terendah berada di desa Banyudono dengan jumlah 7,68\%. Untuk tingkat rasio kemiskinan sedang yaitu desa Ketunggeng dengan skor 20. Hampir semua desa di Kecamatan Dukun berada pada tingkat rendah. Hal ini dikarenakan hampir di semua desa angka perbandingan jumlah penduduk miskin berada pada kriteria $<20 \%$.

Kerentanan ekonomi meliputi luas lahan produktif dan jumlah ternak. Luas lahan produktif tertinggi berada di Desa Ngargomulyo dengan jumlah $436 \mathrm{Ha}$. Luas lahan produktif terendah berada di desa Mangunsoko dengan jumlah $115 \mathrm{Ha}$. Untuk tingkat luas lahan produktif sedang yaitu desa Ketunggeng, Desa Ngadipuro, Desa Wates, Desa Keningar, Desa Mangunsoko, dan Desa Sewukan dengan skor 20. Untuk tingkat luas lahan produktif tinggi berada di Desa Kalibening, Desa Ngargomulyo, Desa Sumber, Desa Dukun, Desa Banyubiru, Desa Banyudono, Desa Krinjing, Desa Paten, dan Desa Sengi dengan skor 30.Jumlah ternak tertinggi berada di Desa Ngargomulyo dengan jumlah 1074 ekor. Jumlah ternak terendah berada di Desa Keningar dengan jumlah 91 ekor. Untuk tingkat ternak terancam rendah yaitu desa Ketunggeng, Desa Ngadipuro, Desa Wates, Desa Keningar, Desa Dukun, Desa Banyubiru, Desa Banyudono, Desa Mangunsoko, dan Desa Sewukan dengan skor 10. Untuk tingkat ternak terancam sedang berada di Desa Kalibening, Desa Sumber, Desa Krinjing, Desa Paten, dan Desa Sengi dengan skor 20. Sedangkan untuk tingkat ternak terancam tinggi berada di Desa Ngargomulyo dengan skor 30.

Kerentanan fisik meliputi jumlah rumah dan jumlah fasilitas umum. Jumlah rumah tertinggi berada di Desa Banyudono dengan jumlah 1.436 buah.Jumlah rumahterendah berada di Desa Keningar dengan jumlah 189 buah. Untuk tingkat jumlah rumah terancam rendah yaitu Desa Wates dan Desa Keningardengan skor 10. Untuk tingkat jumlah rumah terancam sedang berada di Desa Ketunggeng, Desa Ngadipuro, Desa Kalibening, Desa Ngargomulyo, Desa Mangunsoko, dan Desa Sewukan, Desa Krinjing, dan Desa Paten dengan skor 20. Sedangkan untuk tingkat jumlah rumah terancam tinggi berada di Desa Dukun, Desa Banyubiru, Desa Banyudono, Desa Sumber,dan Desa Sengi dengan skor 30.Jumlah fasilitas umum tertinggi berada di Desa Dukun dengan jumlah 72 buah. Jumlah fasilitas umum terendah berada di desa Keningar dengan jumlah 10 buah. Untuk tingkat jumlah fasilitas umum sedang berada di Desa Ngadipuro, Desa Wates, Desa Kalibening, Desa Ngargomulyo, Desa Keningar, Desa Sumber, Desa Mangunsoko, dan Desa Sewukan, Desa Krinjing, Desa Paten, dan Desa Sengi dengan skor 20. Sedangkan untuk tingkat jumlah fasilitas umum tinggi berada di Desa Ketunggeng, Desa Dukun, Desa Banyubiru, Desa Banyudono, dengan skor 30.

Kerentanan Lingkungan berkaitan dengan penggunaan lahan. Penggunaan lahan merupakan perwujudan campur tangan manusia terhadap lingkungannya. Jenis-jenis penggunaan lahan memilki respon yang berbeda-beda terhadap bencana erupsi gunungapi. Hutan akan cenderung memiliki kerentanan kecil dibandingkan dengan 
permukiman. Hal ini karena material-material hasil erupsi gunungapi dapat tertahan oleh hutan, sedangkan permukiman dan sawah akan cenderung meloloskan material-material hasil erupsi gunungapi. Hasil perhitungan kerentanan juga divisualisasikan pada peta sebaran kerentanan di Kecamatan Dukun seperti ditunjukkan oleh Gambar 3 berikut ini.

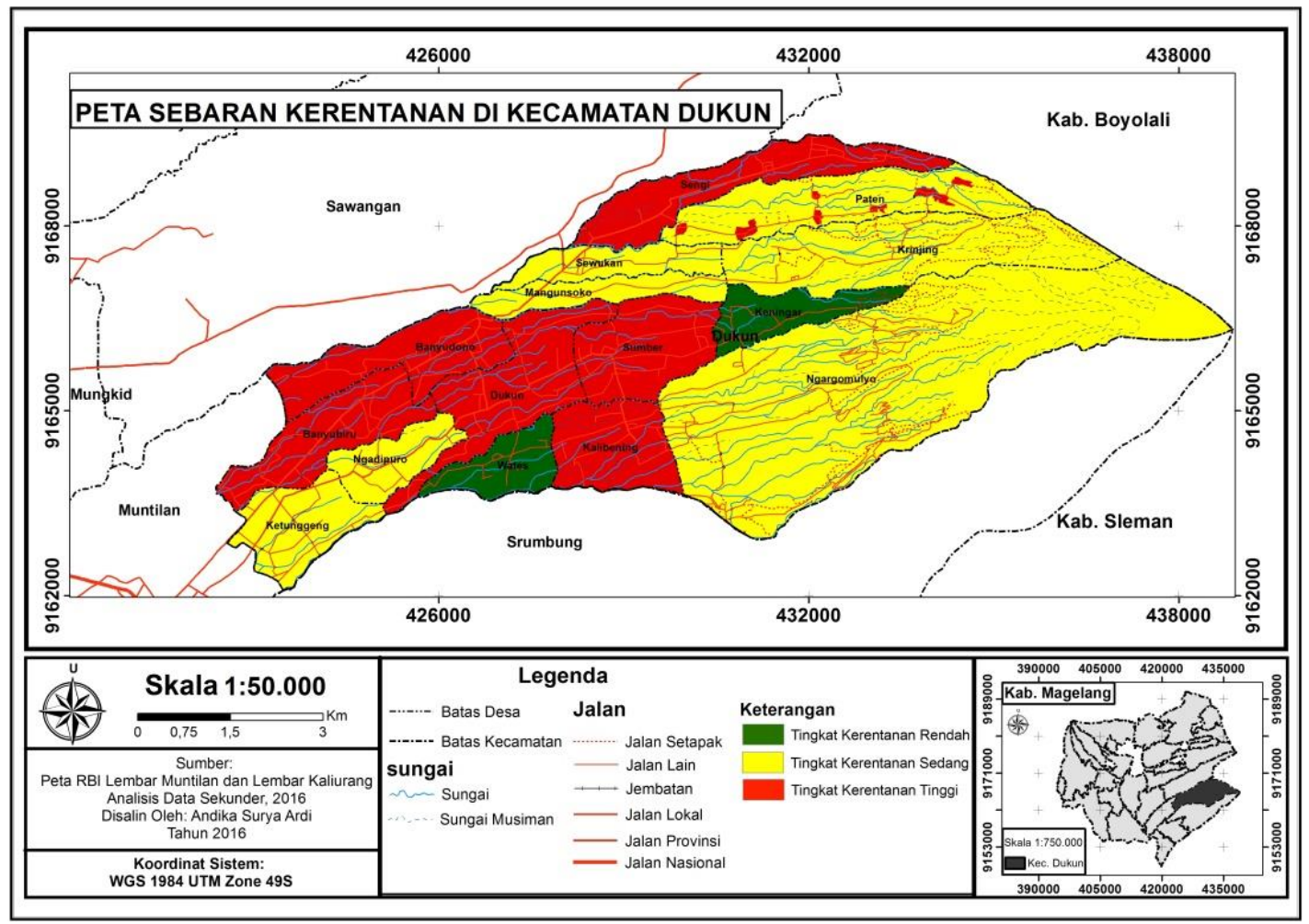

Gambar 3. Peta Tingkat Kerentanan Erupsi Gunung Merapi di Kecamatan Dukun

Langkah selanjutnya adalah melakukan perhitungan kapasitas dalam menghadapi bencana. Indikator yang digunakan antara lain keberadaan organisasi penanggulangan bencana, keberadaan dan jenis sistem peringatan dini, keberadaan dan jenis sosialisasi bencana, keberadaan dan jenis faktor pengurangan risiko dasar, dan keberadaan dan jenis mitigasi bencana.

Dalam kaitannya dengan keberadaan organisasi penanggulangan bencana, semua desa di Kecamatan Dukun terdapat organisasi penanggulangan bencana. Jenis kelembagaan atau organisasi penanggulangan bencana di Kecamatan Dukun berupa Organisasi Pengurangan Risiko Bencana (OPRB). Di beberapa desa terdapat jenis yang lain seperti di Desa Ngargomulyo terdapat Forum Pengurangan Risiko Bencana (FPRB) dan Santri Siaga Bencana (SSB). Sedangkan di Desa Sumber bernama Forum Tangguh Bencana (FORTANA) dan di Desa Sengi berupa Forum Pengurangan Risiko Bencana (FPRB). Organisasi penanggulangan bencana di Kecamatan Dukun dibentuk melalui Rapat Musyawarah Desa dan kemudian diberi Surat Keputusan Kepala Desa. Hampir disemua desa di Kecamatan Dukun terdapat koordinasi yang baik didalam organisasi bencana tersebut. Ada juga kerjasama dengan Organisasi Penanggulangan Bencana 
Daerah berupa pembinaan dan pelatihan. Masyarakat juga terlibat aktif dalam organisasi penanggulangan bencana tersebut.

Mengenai keberadaan dan jenis sistem peringatan dini, semua desa di Kecamatan Dukun terdapat sistem peringatan dini. Jenis sistem peringatan dini di Kecamatan Dukun dapat berupa dalam bentuk yang sederhana seperti kentongan dan pengeras suara masjid dan dapat berupa Sirine tanda bahaya. Hampir disemua Desa di Kecamatan Dukun sistim peringatan dini bencana lewat pengeras suara masjid di masing masing desa. Hanya di Desa Ngargomulyo dan Desa Dukun yang mempunyai Sirine sebagai tanda bahaya erupsi Gunung Merapi.Sirine yang ada dipasang di Balai Desa. Sebagai alat komunikasi, banyak masyarakat atau Kantor Desa yang mempunyai Handy talky (HT).

Dalam hal keberadaan dan jenis sosialisasi bencana, semua desa di Kecamatan Dukun pernah dilakukan sosialisasi bencana.Sosialisasi yang dilakukan berasal dari BPBD, BPPTKG, dan Pasak Merapi. Sosialisasi yang dilakukan berupa materi seputar kebencanaan dan di beberapa dilakukan simulasi terkait penanganan bencana erupsi Gunung Merapi.

Mengenai keberadaan dan jenis faktor pengurangan risiko dasar, semua desa di Kecamatan Dukun terdapat faktor pengurangan risiko dasar. Faktor pengurangan risiko dasar atau aturan baik dari pemerintah ataupun masyarakat yang berhubungan dengan lingkungan hidup maupun penngurangan risiko bencana terkait dengan erupsi Gunung Merapi di setiap desa di Kecamatan Dukun Berupa Prosedur Tetap (PROTAP). Hampir disetiap desa di Kecamatan Dukun aturan tersebut berjalan dengan baik. Untuk kawasan KRB III, PROTAP merupakan salah satu syarat diadakannya MOU sister village (Desa Bersaudara)

Adapun mengenaikeberadaan dan jenis mitigasi bencanaSemua desa di Kecamatan Dukun terdapat mitigasi bencana. Disemua desa di Kecamaatan Dukun terdapat pelatihan pelatihan dalam menghadapi bencana erupsi Gunung Merapi. Di KRB III terdapat sebuah system bernama sister village (desa Bersaudara). Desa bersaudara merupakan gagasan BPBD bersama pemerintah untuk menghadapi bencana erupsi Gunung Merapi yang akan datang. Desa Bersaudara merupakan tujuan pengungsian desa yang ada di KRB III. Hal ini dikarenakan pengalaman erupsi Gunung Merapi 2010, terjadi ketidakjelasan lokasi pengungsian, hingga menyebabkan jatuhnya korban jiwa. Distribusi tingkat kemampuan dalam menghadapi bencana ditunjukkan oleh Gambar 5.

\section{Sebaran Risiko Bencana Erupsi Gunung Merapi Di Kecamatan Dukun Kabupaten Magelang}

Risiko diperoleh dari hasil overlay peta ancaman bahaya, kerentanan total, dan kapasitas. Risiko total terhadap bencana erupsi Gunung Merapi di Kecamatan Dukun memiliki tiga tingkat risiko. Semakin tinggi tingkat risiko maka potensi kerugian akibat terjadinya bencana erupsi Gunung Merapi menjadi lebih besar.Potensi kerugian tersebut berupa kematian, luka, sakit, jiwa, terancam, hilangnya rasa aman, mengungsi, kerusakan atau kehilangan harta, dan gangguan kegiatan masyarakat. Potensi berbagai kerugian ini akan semakin menurun seiring dengan menurunnya tingkat risiko di suatu wilayah. 
Risiko bencana akibat erupsi Gunungapi di Kecamatan Dukun tersebar diseluruh wilayah (Gambar 4).Tingkat risiko sedang mendominasi sebagian wilayah Desa Sengi dan Desa Kalibening. Faktor yang paling mempengaruhi ialah sebagian wilayah yang memiliki tingkat risiko sedang di kedua desa tersebut merupakan wilayah KRB III yang memiliki ancaman bahaya paling tinggi apabila terjadi erupsi Gunung Merapi. Faktor lain yang mempengaruhi ialah dominasi tingkat kerentanan sangat tinggi dan tingkat kapasitas yang rendah di wilayah ini.

Tingkat risiko rendah mendominasi wilayah besar wilayah Desa Ketunggeng, Desa Banyubiru, Desa Ngadipuro, Desa Wates dan Desa Banyudono. Wilayah dengan tingkat risiko rendah ini memiliki tingkat kerentanan sangat tinggi dan kapasitas rendah, akan tetapi sebagian besar wilayah dengan tingkat risiko rendah berada di wilayah KRB I yang memiliki ancaman bahaya paling rendah, akan tetapi memiliki kapasitas yang rendah. Tingkat risiko sangat rendah berada di Desa Sewukan, Mangunsoko, Dukun, Kalibening, Sumber, Paten, Krinjing, Sengi dan Ngargomulyo.Walaupun diwilayah ini merupakan KRB III yang merupakan ancaman paling tinggi, wilayah ini mempunyai kapasitas yang tinggi juga sehingga menyebabkan risiko yang sangat rendah.

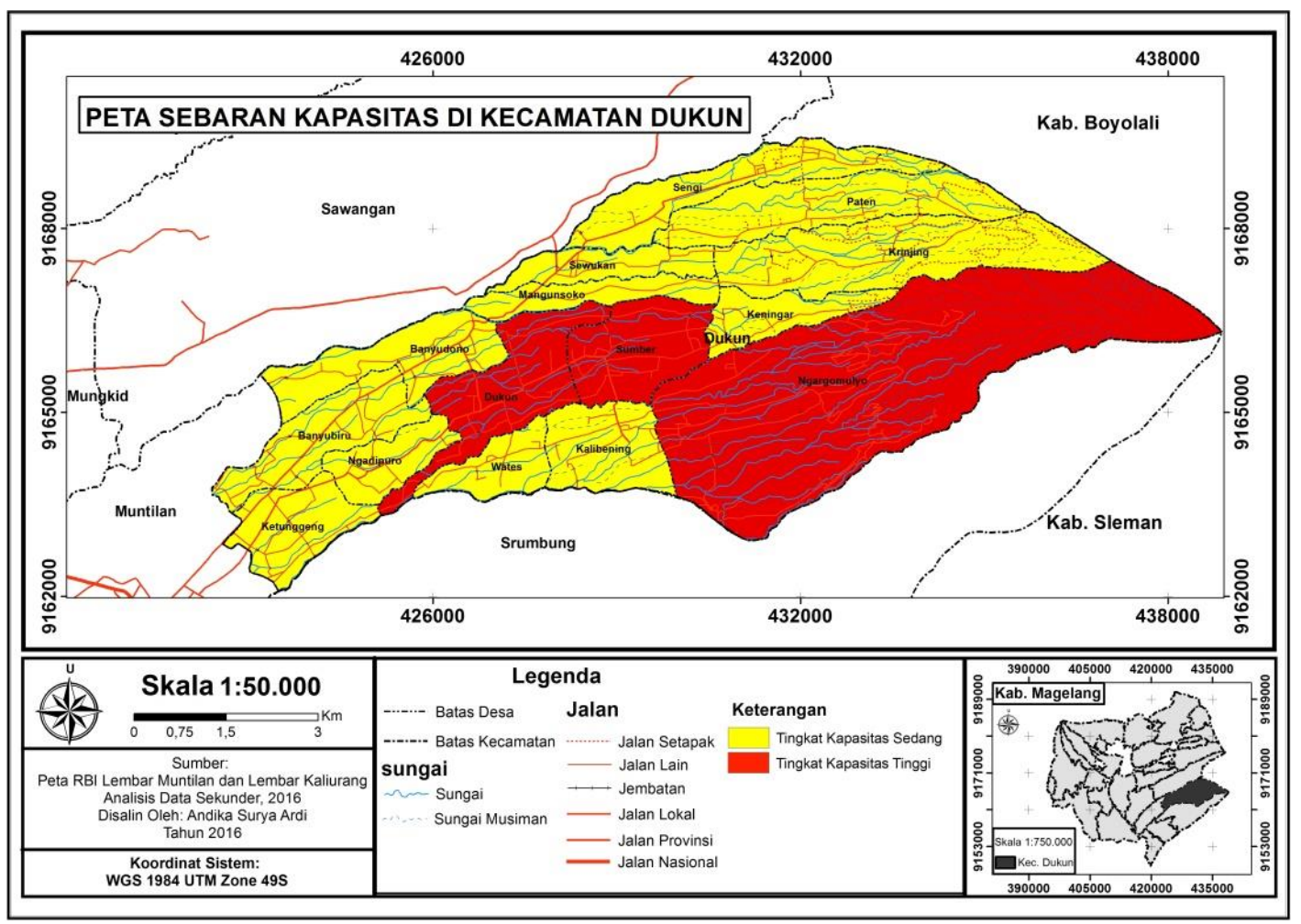

Gambar 4. Peta Tingkat dan Sebaran Kapasitas Erupsi Gunung Merapi di Kecamatan Dukun 


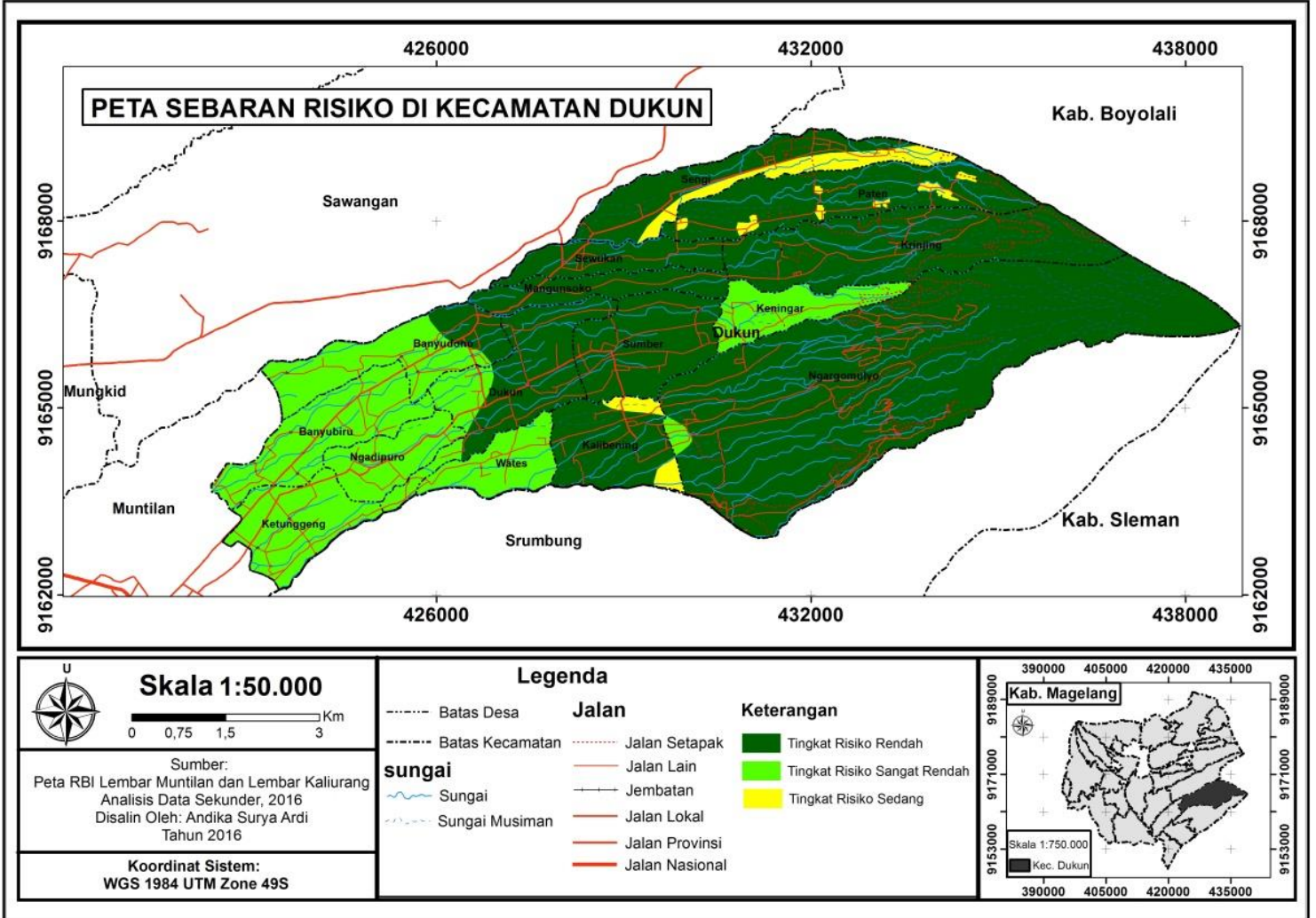

Gambar 5. Peta Tingkat dan Sebaran Risiko Erupsi Gunung Merapi di Kecamatan Dukun

\section{SIMPULAN}

Tingkat risiko bencana erupsi Gunung Merapi di Kecamatan Dukun memiliki beberapa tingkatan risiko. Tingkat risiko dibagi menjadi tiga tingkat yaitu sedang, rendah, dan sangat rendah. Semakin tinggi tingkat risiko bencana maka potensi kerugian akibat terjadinya bencana erupsi Gunung Merapi semakin besar yaitu berupa kematian, luka, sakit, jiwa terancam, hilangnya rasa aman, kerusakan atau kehilangan harta, dan gangguan kegiatan masyarakat.

Sebaran risiko bencana akibat erupsi Gunungapi di Kecamatan Dukun tersebar diseluruh wilayah. Sebaran risiko dengan tingkat risiko sedang mendominasi sebagian wilayah Desa Sengi dan Desa Kalibening. Sebaran risiko dengan tingkat risiko rendah mendominasi sebagian besar wilayah Desa Ketunggeng, Desa Banyubiru, Desa Ngadipuro, Desa Wates dan Desa Banyudono. Sebaran risiko dengan tingkat risiko sangat rendah berada di Desa Sewukan, Mangunsoko, Dukun, Kalibening, Sumber, Paten, Krinjing, Sengi dan Ngargomulyo.

\section{UCAPAN TERIMA KASIH}

Dalam kesempatan ini penulis mengucapkan terima kasih kepada berbagai pihak yang telah membantu dalam proses penelitian ini baik dalam tahap pengambilan data maupun analisis data, khususnya kepada ibu Dr. Dyah Respati selaku pembimbing. 


\section{DAFTAR PUSTAKA}

Setyawati, S., Hadi, B.S., dan Ashari, A. 2013. Pengembangan Sistem Informasi Bahaya Erupsi untuk Pengelolaan Kebencanaan di Lereng Selatan Gunungapi Merapi. Majalah Geografi Indonesia 27 (2): 138-148

Setyawati, S., Hadi, B.S., dan Ashari, A. 2015. The Analysis of Eruption Hazard of the Merapi Volcano After 2010 Eruption Disasters. Proceedings 9th International Conference on Malaysia-Indonesia Relations (PAHMI 9). Universitas Negeri Yogyakarta - Universiti Malaya 2015.

Sudibyakto. (2011). Manajemen Bencana di Indonesia ke Mana?. Yogyakarta: Gadjah Mada University Press.

Sutikno., Santosa, L.W., Kurniawan, A., Purwanto, T.H. 2007. "Kerajaan Merapi" Sumberdaya Alam dan Daya Dukungnya.Yogyakarta: Badan Penerbit Fakultas Geografi.

Ma'arif, S dan Hizbaron, D.R. (2014).Strategi Menuju Masyarakat Tangguh Bencana Dalam Preespektif Sosial. Yogyakarta: UGM Press

Verstappen. (2013). Garis Besar Geomorfologi Indonesia (Terjemahan Sutikno). Yogyakarta: Gadjah Mada University Press.

Wesnawa, I.G.A dan Christiawan, P.I. (2014).Geografi Bencana. Yogyakarta: Graha Ilmu 